7-2019

Ossification of the cruciform ligament of atlas; a rare cause of cervical myelopathy: Case report and review of literature

Muhammad Waqas Saeed Baqai

Gohar Javed

Mirza Zain Baig

Follow this and additional works at: https://ecommons.aku.edu/pakistan_fhs_mc_surg_neurosurg

Part of the Neurology Commons, and the Surgery Commons 


\section{Ossification of the Cruciform Ligament of Atlas; a Rare Cause of Cervical Myelopathy: Case Report and Review of Literature}

\begin{abstract}
We present a case of cervical myelopathy secondary to ossification of the cruciform ligament (also known as cruciate ligament). This is a rare phenomenon that, to the best of our knowledge, has only been reported 16 times previously in literature. We have added a review of literature after our case presentation. We hope that by doing so, we may aid clinicians reach early diagnosis so as to be able to better manage this rare disease.
\end{abstract}

Keywords: Cruciform ligament, ossification, spine

\section{Introduction}

Ossification of the cruciform ligament (also known as cruciate ligament) of atlas is a rare phenomenon. ${ }^{[1-4]}$ To the best of our knowledge, there have been only 16 cases reported in literature thus far. In this article, we present a case of cervical myelopathy secondary to ossification of the cruciform ligament of atlas. We have also provided a concise review of literature pertaining to this pathology.

\section{Case Report}

A 48-year-old male presented to our neurosurgery clinic with a complaint of pain in the bilateral lower limbs along with progressive weakness in all four extremities for the past 4 years as well as urinary incontinence for the past 1 year. He became bed bound and catheter dependent. He was treated for suspected cervical spine tuberculosis for 6 months by antituberculosis therapy at an outside institute, but there were no confirmatory tests done. He did not provide us with any other relevant history.

On examination, he was a middle-aged male with a body mass index of $30 \mathrm{~kg} / \mathrm{m}^{2}$ and wheel chair bound. He was alert, awake, and oriented to time, place, and person. He did not exhibit any cranial nerve deficits. His motor examination showed normal bulk, increased tone, and power of $0 / 5$ in

\footnotetext{
This is an open access journal, and articles are distributed under the terms of the Creative Commons Attribution-NonCommercial-ShareAlike 4.0 License, which allows others to remix, tweak, and build upon the work non-commercially, as long as appropriate credit is given and the new creations are licensed under the identical terms.
}

For reprints contact: reprints@medknow.com all muscle groups of both upper and lower limbs bilaterally. He also had hyperactive deep tendon reflexes of the biceps, triceps, brachioradialis, patellar, and Achilles tendons. Planters were up going along with sustained clonus bilaterally. Anal tone was lax.

Computed tomography (CT) scan [Figures 1 and 2] showed ossification of the entire cruciform ligament along with pseudarthrosis of $\mathrm{C} 1$ and $\mathrm{C} 2$ vertebra. Magnetic resonance imaging (MRI) [Figure 3] revealed severe cervical cord stenosis.

The patient was explained in detail about the following three options: prolonged application of hard collar, halo ring traction, and surgical decompression. Due to chronic nature of his symptoms and belonging to a remote area making regular follow-ups difficult in case of halo traction and hard collar, the patient opted for surgical decompression. He was counseled about the risks including but not limited to cervical cord injury, visceral injury, failed decompression, and persistence of symptoms. After developing an understanding on risks and benefits, informed consent was taken and we did a neuronavigation-guided transoral decompression of $\mathrm{C} 1$ and $\mathrm{C} 2$. Highly vascular pseudarthrosis along $\mathrm{C} 1$ and $\mathrm{C} 2$ anterior arches and ossification of cruciate ligament (both transverse and longitudinal components) were noticed. Maximum safe debulking was performed.

How to cite this article: Baqai MW, Javed G, Baig MZ. Ossification of the cruciform ligament of atlas; a rare cause of cervical myelopathy: Case report and review of literature. Asian J Neurosurg 2019;14:999-1003.

\section{Muhammad Waqas Saeed Baqai, Gohar Javed, Mirza Zain Baig ${ }^{1}$}

Department of Surgery, Section of Neurosurgery, Aga Khan University Hospital, Karachi,

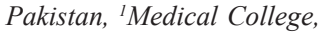
Aga Khan University Hospital, Karachi, Pakistan

Address for correspondence: Dr. Gohar Javed, Department of Surgery, Section of Neurosurgery, Aga Khan University Hospital, Karachi, Pakistan.

E-mail: gohar.javed@aku.edu

Access this article online

Website: www.asianjns.org

DOI: 10.4103/ajns.AJNS_76_19

Quick Response Code:

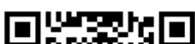

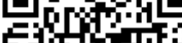
iptrats irtir:

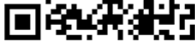




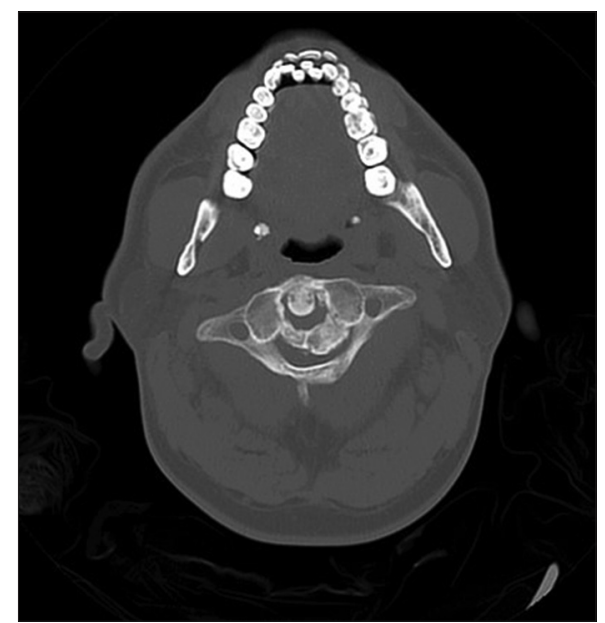

Figure 1: Computed tomography axial section showing ossification of the entire transverse ligament

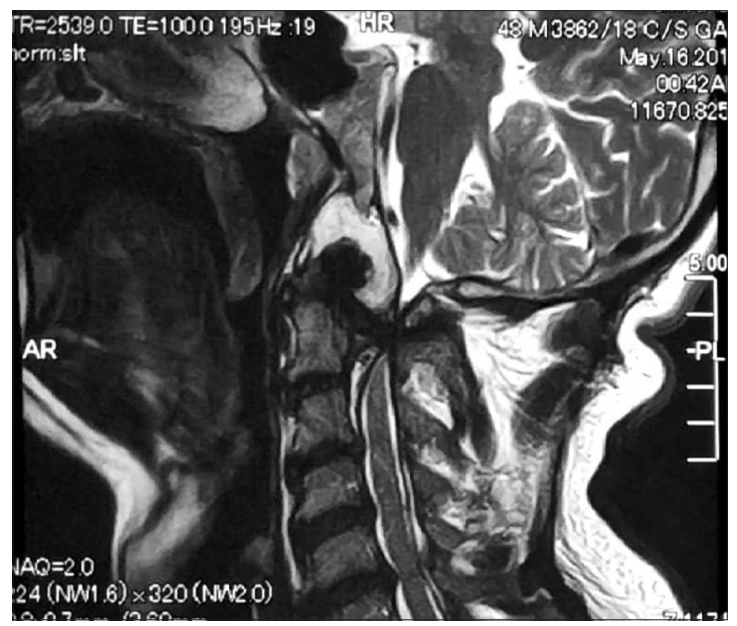

Figure 3: T2 magnetic resonance imaging cervical spine sagittal section showing severe cord compression. Unidentified bright object in spine visualized in the magnetic resonance imaging was most likely secondary to ligament hypertrophy

Due to the main bulk of the ossified ligament seen anterior to the cord as well as the anterior compression of the cervical spine, we opted for an anterior approach as opposed to a posterior or 360 approach. Our patient and his family were kept in confidence that there may be a need of another procedure if complete debulking could not be done anteriorly.

Postoperative CT [Figures 4 and 5] scan was also performed which showed nonvisualization of the anterior tubercle, anterior arch, part of posterior arch of the atlas, and dens and pedicle of axis vertebra, with resultant widening of the spinal canal. Postoperative MRI was not done as the patient showed subjective and objective improvement. He had severe financial issues and MRI is a costly investigation in our country.

He was shifted to the intensive care unit for $24 \mathrm{~h}$ postoperatively and later shifted out. His neurological signs improved after 2 weeks with a power of $4 / 5$ in

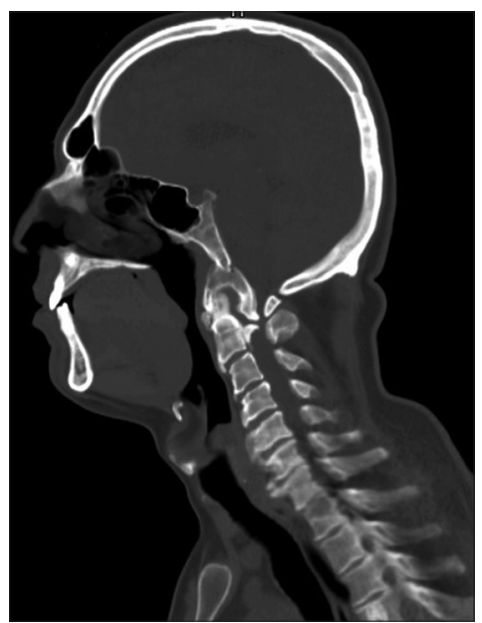

Figure 2: Computed tomography scan, sagittal image showing pseudoarthrosis of atlas along with ossification of longitudinal band of cruciform ligament

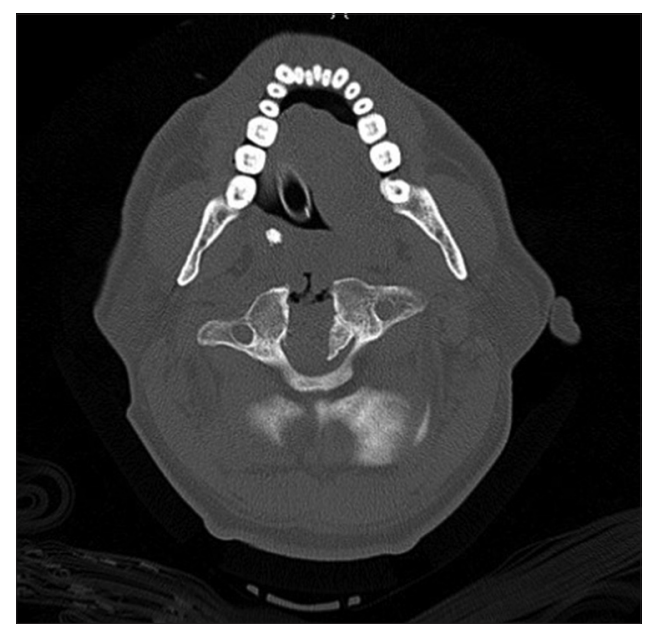

Figure 4: Postoperative computed tomography scan showing removal of most of the transverse ligament

the left hand and $3 / 5$ both proximally and distally in left the lower limb, right upper limb, and lower limb. He had no pain or any other postoperative complication. Physiotherapy and rehabilitation program were initiated. On 3-month follow-up, he was able to stand with support and his motor examination improved to $4+$ power in all groups bilaterally in both upper and lower limbs.

\section{Discussion}

Ossification of the atlantal ligament was first described in literature in 1978 by a case report on two patients by Wackenham. ${ }^{[5,6]}$ Another three cases were then published in 1979 by Dietemann. Please note that the above-mentioned articles were only available in French and we, to the best of our efforts, were unable to find full-text English translations. They have therefore not been included in Table 1 that contains a summary of cases of atlantal ligament ossification reported in the literature to date. 


\begin{tabular}{|c|c|c|c|c|c|}
\hline Article & Patient & Clinical features & Radiological findings & Management & Outcome \\
\hline $\begin{array}{l}\text { Hayashi } \\
\text { et al., } \\
1998^{[9]}\end{array}$ & $\begin{array}{c}68, \\
\text { male }\end{array}$ & $\begin{array}{l}\text { Progressive spastic quadriparesis } \\
\text { below C5 } \\
\text { Disturbed pain and touch sensation } \\
\text { in all four limbs } \\
\text { Bowel and bladder dysfunction }\end{array}$ & $\begin{array}{l}\text { X-ray: Ossified mass at the back } \\
\text { of dens, anterior shift of atlas } \\
\text { CT: High-density mass around } \\
\text { the dens, which contained an } \\
\text { area of low density } \\
\text { T1 MR: High-intensity mass } \\
\text { lesion at the back of dens } \\
\text { T2 MR: Spinal canal stenosis at } \\
\text { cervicomedullary junction }\end{array}$ & $\begin{array}{l}\text { Suboccipital } \\
\text { decompression and } \\
\text { resection of posterior } \\
\text { arch of atlas } \\
\text { C4-C6 laminoplasty }\end{array}$ & $\begin{array}{l}\text { Spasticity in lower } \\
\text { extremities resolved } \\
\text { Physical therapy } \\
\text { helped regain full } \\
\text { range of motion of } \\
\text { limbs } \\
\text { Paresthesia and } \\
\text { sphincter disturbances } \\
\text { resolved }\end{array}$ \\
\hline $\begin{array}{l}\text { Tsuruta } \\
\text { et al., } \\
2003^{[8]}\end{array}$ & $\begin{array}{l}79, \\
\text { female }\end{array}$ & $\begin{array}{l}\text { Occipitalgia and impaired gait } \\
\text { Right-sided hemiparesis } \\
\text { Bilateral loss of sensations in upper } \\
\text { limbs } \\
\text { Hyperreflexia } \\
\text { Positive Babinski's and Hoffman's }\end{array}$ & $\begin{array}{l}\text { X-ray: Reduced spinal canal } \\
\text { diameter and anterior position } \\
\text { of the posterior arch of atlas } \\
\text { MRI: Spinal cord compression } \\
\text { at atlas and C3-C4 vertebrae } \\
\text { CT myelography: Narrowing of } \\
\text { spinal canal and ossification of } \\
\text { transverse ligament }\end{array}$ & Atlas laminectomy & $\begin{array}{l}\text { Occipitalgia resolved } \\
\text { and right hemiparesis } \\
\text { improved }\end{array}$ \\
\hline $\begin{array}{l}\text { Griesdale } \\
\text { et al., } \\
2003^{[10]}\end{array}$ & $\begin{array}{l}70, \\
\text { female }\end{array}$ & $\begin{array}{l}\text { Numbness in lower extremities, left } \\
\text { hand, and trunk } \\
\text { Weakness in left hand, deltoid, and } \\
\text { hip flexors } \\
\text { Buzzing sensation down the left side } \\
\text { with neck extension } \\
\text { History of tuberculous, peritonitis, } \\
\text { and carpal tunnel syndrome. } \\
\text { Increased tone in lower extremities } \\
\text { Brisk reflexes } \\
\text { Spastic gait }\end{array}$ & $\begin{array}{l}\text { X-ray: C1-C2 instability, } \\
\text { increase in atlantodental interval } \\
\text { from } 4 \mathrm{~mm} \text { in the neutral } \\
\text { position to } 9 \mathrm{~mm} \text { in flexion } \\
\mathrm{CT} \text { : Minimal calcification } \\
\text { MRI: Retro-odontoid, } \\
\text { extradural mass-causing spinal } \\
\text { cord compression. Hypointense } \\
\text { on T1 and hyperintense on T2. } \\
\text { Minimal enhancement with } \\
\text { gadolinium }\end{array}$ & $\begin{array}{l}\text { Transoral resection } \\
\text { of the odontoid } \\
\text { and extradural } \\
\text { retro-odontoid } \\
\text { mass. Posterior } \\
\text { C1-C2 stabilization } \\
\text { with right-sided } \\
\text { transarticular screw } \\
\text { and interlaminar } \\
\text { fusion }\end{array}$ & $\begin{array}{l}\text { Complete resolution } \\
\text { of symptoms at } 6 \\
\text { months }\end{array}$ \\
\hline $\begin{array}{l}\text { Wang } \\
\text { et al., } \\
2004^{[5]}\end{array}$ & $\begin{array}{c}66, \\
\text { male }\end{array}$ & $\begin{array}{l}\text { Neck pain with limited neck motion } \\
\text { Paresis and weakness of all four } \\
\text { extremities } \\
\text { Gait disturbance } \\
\text { Hyperactive reflexes } \\
\text { Hoffman and Babinski reflexes } \\
\text { bilaterally positive } \\
\text { Bilateral sustained ankle clonus } \\
\text { Hypoesthesia below the angle of the } \\
\text { sternum bilaterally }\end{array}$ & $\begin{array}{l}\text { X-ray: Diffuse densification of } \\
\text { vertebral bodies } \\
\text { CT: OTAL } \\
\text { Ossification of posterior } \\
\text { longitudinal ligament at C2 } \\
\text { Ossification of posterior } \\
\text { longitudinal ligament from C3 } \\
\text { to C7 }\end{array}$ & $\begin{array}{l}\text { Halo ring traction } \\
\text { with } 4 \mathrm{~kg} \text { weight } \\
\text { Hard cervical brace } \\
\text { protection }\end{array}$ & $\begin{array}{l}\text { Symptoms improved } \\
\text { with conservative } \\
\text { management } \\
\text { JOA score increased } \\
\text { from } 7 \text { to } 13\end{array}$ \\
\hline $\begin{array}{l}\text { Wang } \\
\text { et al., } \\
2004^{[5]}\end{array}$ & $\begin{array}{l}60, \\
\text { male }\end{array}$ & $\begin{array}{l}\text { Moderate motor weakness of the } \\
\text { upper extremity } \\
\text { Hyperactive reflexes } \\
\text { Hoffman and Babinski reflexes } \\
\text { bilaterally positive } \\
\text { Bilateral sustained ankle clonus } \\
\text { Bilateral hypoesthesia on upper } \\
\text { extremity }\end{array}$ & $\begin{array}{l}\text { X-ray: Ossification of posterior } \\
\text { longitudinal ligament at } \mathrm{C} 1-\mathrm{C} 7 \\
\mathrm{CT} \text { : OTAL at } \mathrm{C} 1 \\
\text { (posterior to the dens) and } \\
\text { ossification of posterior } \\
\text { longitudinal ligament at } \mathrm{C} 2-\mathrm{C} 7\end{array}$ & $\begin{array}{l}\text { Halo ring traction } \\
\text { with } 4 \mathrm{~kg} \text { weight } \\
\text { Hard cervical brace } \\
\text { protection }\end{array}$ & $\begin{array}{l}\text { JOA score increased } \\
\text { from } 8 \text { to } 12\end{array}$ \\
\hline $\begin{array}{l}\text { Shoda } \\
\text { et al., } \\
2005^{[4]}\end{array}$ & $\begin{array}{l}70, \\
\text { male }\end{array}$ & $\begin{array}{l}\text { Progressive neck pain and numbness } \\
\text { of extremities } \\
\text { Spastic quadriparesis } \\
\text { Spastic gait } \\
\text { Hyperreflexia } \\
\text { Frequent urination }\end{array}$ & $\begin{array}{l}\text { X-ray and CT: Ossification of } \\
\text { posterior atlantoaxial membrane } \\
\text { and transverse atlantal ligament }\end{array}$ & $\begin{array}{l}\text { Decompressive } \\
\text { resection of the } \\
\text { posterior arc } \\
\text { of the atlas and } \\
\text { laminectomy of the } \\
\text { axis }\end{array}$ & $\begin{array}{l}\text { Marked improvement } \\
\text { in symptoms }\end{array}$ \\
\hline
\end{tabular}




\begin{tabular}{|c|c|c|c|c|c|}
\hline \multicolumn{6}{|c|}{ Table 1: Contd... } \\
\hline Article & Patient & Clinical features & Radiological findings & Management & Outcome \\
\hline $\begin{array}{l}\text { Tang } \\
\text { et al., } \\
2010^{[1]}\end{array}$ & $\begin{array}{c}58, \\
\text { female }\end{array}$ & $\begin{array}{l}\text { Neck pain and limited neck motion } \\
\text { Numbness of all } 4 \text { limbs } \\
\text { Disturbance of Gait } \\
\text { Hyperactive reflexes } \\
\text { Positive Hoffmann's sign in left hand }\end{array}$ & $\begin{array}{l}\text { X-ray: Hypoplastic posterior } \\
\text { arch of atlas, hypertrophic dens, } \\
\text { stenosis of the spinal canal at } \\
\text { the level of atlas } \\
\text { CT: marked stenosis at C1 } \\
\text { Hypoplastic but intact posterior } \\
\text { arch of the atlas, partially } \\
\text { ossified transverse ligament, } \\
\text { and hypertrophic dens }\end{array}$ & $\begin{array}{l}\text { Decompressive } \\
\text { resection of posterior } \\
\text { arch of the atlas }\end{array}$ & $\begin{array}{l}\text { Improvement in } \\
\text { numbness and gait }\end{array}$ \\
\hline $\begin{array}{l}\text { Proietti } \\
\text { et al., } \\
2011^{[3]}\end{array}$ & $\begin{array}{l}53, \\
\text { female }\end{array}$ & $\begin{array}{l}\text { Progressive neck pain, suboccipital } \\
\text { headache and limited motion of } \\
\text { cervical spine } \\
\text { Spastic quadriparesis } \\
\text { Numbness of extremities } \\
\text { Hyperactive reflexes } \\
\text { Bilateral Babinski and Hoffmann } \\
\text { signs } \\
\text { Loss of fine motor skills } \\
\text { Spastic broad-based and hesitant gait }\end{array}$ & $\begin{array}{l}\text { CT: Hypoplastic posterior } \\
\text { arch of the atlas, ossification } \\
\text { of the transverse ligament and } \\
\text { ossification localized } \\
\text { Between odontoidal apex and } \\
\text { occipital lamina }\end{array}$ & $\begin{array}{l}\text { C1 laminectomy and } \\
\text { fixation with two } \\
\text { lateral mass } \\
\text { Polyaxial screws } \\
\text { in the atlas and two } \\
\text { bilateral crossing C2 } \\
\text { laminar screws } \\
\text { C1-C2 fusion was } \\
\text { performed with } \\
\text { autologous iliac crest } \\
\text { bone graft }\end{array}$ & $\begin{array}{l}\text { Improvement in } \\
\text { neurological functions }\end{array}$ \\
\hline $\begin{array}{l}\text { Sasaji } \\
\text { et al., } \\
2011^{[2]}\end{array}$ & $\begin{array}{l}76, \\
\text { female }\end{array}$ & $\begin{array}{l}\text { Numbness and clumsiness in upper } \\
\text { limbs } \\
\text { Gait disturbance }\end{array}$ & $\begin{array}{l}\text { X-ray: Irreducible atlantoaxial } \\
\text { subluxation } \\
\text { CT: OTAL, coalition of } \\
\text { atlanto-occipital joints and } \\
\text { osteoarthritis of the atlantoaxial } \\
\text { joints with degenerated dens } \\
\text { MR: Spinal cord compression } \\
\text { at C1 by the ossification of TLA } \\
\text { and AAS }\end{array}$ & $\begin{array}{l}\text { Decompressive } \\
\text { resection of posterior } \\
\text { arch of atlas and } \\
\text { laminectomy of C3 } \\
\text { and C4 }\end{array}$ & $\begin{array}{l}\text { Improvement in } \\
\text { symptoms }\end{array}$ \\
\hline $\begin{array}{l}\text { Bokhari } \\
\text { and } \\
\text { Baeesa } \\
2012^{[7]}\end{array}$ & $\begin{array}{c}68, \\
\text { female }\end{array}$ & $\begin{array}{l}\text { Chronic cervicalgia } \\
\text { Significant quadriparesis } \\
\text { Hypoesthesia of the upper } \\
\text { extremities } \\
\text { Hyperreflexia } \\
\text { Positive Babinski's sign. Gait } \\
\text { disturbance }\end{array}$ & $\begin{array}{l}\text { X-ray: Degenerative disks at } \\
\text { multiple levels } \\
\text { MR: Canal stenosis and cord } \\
\text { compression at atlas } \\
\text { CT: Canal stenosis, hypoplastic } \\
\text { posterior arch of atlas, OTAL }\end{array}$ & $\begin{array}{l}\text { Laminectomy of } \\
\text { hypoplastic posterior } \\
\text { arch of the atlas }\end{array}$ & $\begin{array}{l}\text { Improvement in } \\
\text { symptoms with } \\
\text { physiotherapy }\end{array}$ \\
\hline $\begin{array}{l}\text { Zhang } \\
\text { et al., } \\
2014^{[6]}\end{array}$ & $\begin{array}{l}64, \\
\text { male }\end{array}$ & $\begin{array}{l}\text { Lower extremity weakness and } \\
\text { clumsiness } \\
\text { Gait disturbance } \\
\text { Hyperactive reflexes in lower } \\
\text { extremity } \\
\text { Positive Hoffmann's sign in the left } \\
\text { hand }\end{array}$ & $\begin{array}{l}\text { X-ray: Continuous arch from } \\
\text { C1 to C5. Disappearance of } \\
\text { bilateral sacroiliac joint space } \\
\text { CT scan: OTAL, Posterior } \\
\text { longitudinal ligament from } \\
\text { C2 to C5 and thoracic spine, } \\
\text { ligamentum flavum in the } \\
\text { thoracic spine }\end{array}$ & $\begin{array}{l}\text { Decompressive } \\
\text { laminectomy for } \\
\text { thoracic spine } \\
\text { Conservative } \\
\text { management for } \\
\text { OTAL }\end{array}$ & \\
\hline
\end{tabular}

MR - Magnetic resonance; MRI - Magnetic resonance imaging; CT - Computed tomography; JOA - Japanese orthopedic association; TLA - Transverse ligament of the atlas; OTAL - Ossification of transverse atlantal ligament; AAS - Atlanto-axial subluxation

Cervical canal stenosis is a rare occurrence at the level of the atlas. This is due to a protective regional anatomy. The canal diameter at the retrodental level is around 17-25 $\mathrm{mm}$, whereas the spinal cord diameter is between 10 and $12 \mathrm{~mm}$. Consequently, for compression to occur at, this level would require a significantly large lesion or a compromise of the bony canal (congenital anomalies, trauma, intervention). ${ }^{[6,7]}$
Ossification of the atlantal ligament may be due to calcium phosphate metabolic disease, obesity, diabetes mellitus, aging, and dynamic factors such as trauma. ${ }^{[8,9]}$ High amounts of fluoride have also been suggested as a possible cause by Wang et $a l^{[5]}$ A possible etiological cause in our patient could not be recognized. Ossification of the atlantal ligament may also be associated with other developmental anomalies at the craniovertebral junction such as hypoplasia of the atlas. ${ }^{[5,7,8]}$ 


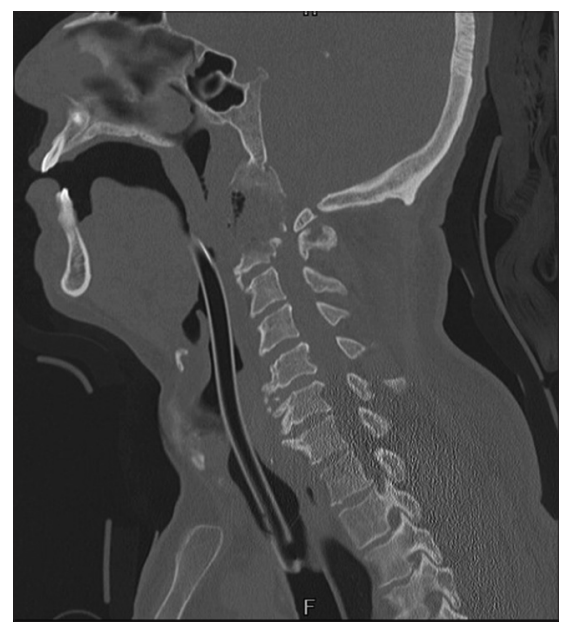

Figure 5: Postoperative sagittal image revealing excision of pseudarthrosis bone and ossified longitudinal band

Clinically, the disease presents as neck pain, stiffness, and features of myelopathy. ${ }^{[10]}$ Treatment is controversial and should be tailored to the severity of the patient's presentation. Wang et $a l^{[5]}$ reported success with conservative therapies such as hard collar and halo ring traction. Others favored surgical decompression.

Table 1 provided detailed summary on the presentation, imaging findings, treatment, and prognosis of previously reported patients with ossification of the atlantal ligament.

\section{Conclusion}

We report a rare case of atlantal ligament ossification that presented to our institution in June 2018. Our patient was managed surgically and has shown improvement in his symptoms. We are hopeful that with further rehabilitation and physical therapy, he will continue to improve. By supplementing our case report with a review of literature, we hope to provide a detailed overview of this disease so as to help clinicians better manage this rare entity.

\section{Declaration of patient consent}

The authors certify that they have obtained all appropriate patient consent forms. In the form, the patient has given his consent for his images and other clinical information to be reported in the journal. The patient understands that his name and initials will not be published and due efforts will be made to conceal identity, but anonymity cannot be guaranteed.

Financial support and sponsorship

Nil.

Conflicts of interest

There are no conflicts of interest.

\section{References}

1. Tang JG, Hou SX, Shang WL, Wu WW. Cervical myelopathy caused by anomalies at the level of atlas. Spine (Phila Pa 1976) 2010;35:E77-9.

2. Sasaji T, Kawahara C, Matsumoto F. Ossification of transverse ligament of atlas causing cervical myelopathy: A case report and review of the literature. Case Rep Med 2011;2011:238748.

3. Proietti L, Scaramuzzo L, Sessa S, Schirò GR, Logroscino CA. Cervical myelopathy due to ossification of the transverse atlantal ligament: A Caucasian case report operated on and literature analysis. Orthop Traumatol Surg Res 2012;98:470-4.

4. Shoda N, Anamizu Y, Yonezawa N, Ishibashi H, Yamamoto S. Ossification of the posterior atlantoaxial membrane and the transverse atlantal ligament. Spine (Phila $\mathrm{Pa}$ 1976) 2005;30:E248-50.

5. Wang W, Kong L, Zhao H, Jia Z. Ossification of the transverse atlantal ligament associated with fluorosis: A report of two cases and review of the literature. Spine (Phila $\mathrm{Pa}$ 1976) 2004;29:E75-8.

6. Zhang Z, Liu Z, Zhu J. Ossification of the transverse atlantal ligament in ankylosing spondylitis - A case report. Biomed Res 2014;25:617-9.

7. Bokhari R, Baeesa S. Atlas hypoplasia and ossification of the transverse atlantal ligament: A rare cause of cervical myelopathy. Case Rep Neurol Med 2012;2012:893284.

8. Tsuruta W, Yanaka K, Okazaki M, Matsumura A, Nose T. Cervical myelopathy caused by hypoplasia of the atlas and ossification of the transverse ligament - Case report. Neurol Med Chir (Tokyo) 2003;43:55-9.

9. Hayashi T, Hirose Y, Sagoh M, Murakami H. Ossification of transverse ligament of the atlas associated with atlanto-axial dislocation - Case report. Neurol Med Chir (Tokyo) 1998;38:425-8.

10. Griesdale DE Jr., Boyd M, Sahjpaul RL. Pseudogout of the transverse atlantal ligament: An unusual cause of cervical myelopathy. Can J Neurol Sci 2004;31:273-5. 